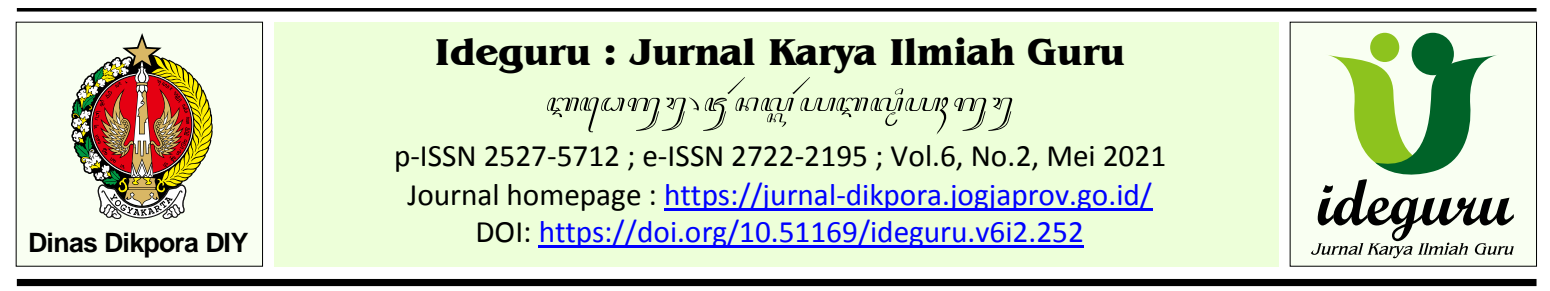

Artikel Penelitian - Naskah dikirim: 01/03/2021 - Selesai revisi: 09/04/2021 - Disetujui: 10/04/2021 - Diterbitkan: 01/05/2021

\title{
Penerapan Mind Mapping untuk Meningkatkan Prestasi Belajar pada Topik Kegiatan Ekonomi
}

\author{
Wardayadi \\ SMA Negeri 1 Bambanglipuro \\ wardayadissmabambanglipuro@yahoo.com
}

\begin{abstract}
Abstrak: Riset ini bertujuan untuk mengetahui penerapan model pembelajaran mind mapping dalam meningkatkan prestasi belajar topik kegiatan ekonomi siswa kelas X IPS 1 di SMAN 1 Bambanglipuro tahun ajaran 2020/2021. Selain itu juga untuk mengetahui proses pelaksanaan pembelajaran yang menerapkan model mind mapping dalam meningkatkan prestasi belajar topik kegiatan ekonomi. Penelitian ini adalah penelitian kualitatif yang menggunakan teknik Penelitian Tindakan Kelas. Model Penelitian Tindakan Kelas ini memakai model Kemmis McTaggart dan dijalankan dalam 2 siklus. Prinsip utama model ini adalah memberikan tindakan dalam siklus bertahap, di mana terdapat empat tahapan utama kegiatan, yaitu: perencanaan, tindakan, observasi dan refleksi. Alat pengumpul data yang dipakai adalah observasi kelas, tes prestasi belajar, dan studi dokumentasi. Observasi dilaksanakan langsung pada proses tindakan. Analisis data menggunakan analisis secara diskriptif analitik dengan penyajian tabel-tabel dan persentase. Penyajian data bentuk persentase selanjutnya didskripsikan dan diambil kesimpulan. Hasil riset ini menujukan penerapan model pembelajaran mind mapping dapat menaikkan prestasi belajar siswa. Peningkatan prestasi terlihat pada siklus I ada 14 siswa (51,58\%) yang nilainya $\geq 70$ atau nilainya sudah KKM dan pada siklus II ada 24 siswa $(88,89 \%)$ yang nilainya $\geq 70$ atau nilainya sudah KKM maka peningkatan ketuntasan belajar sebesar 37,04\% dan peningkatan rerata prestasi belajar siklus I ke siklus II sebesar 14,81 yaitu dari nilai rerata 62,04 pada siklus I menjadi nilai rerata 76,85 pada siklus II. Hasil Afektif siswa juga naik yakni siklus I hanya kategori cukup dan pada siklus II menjadi sangat baik.
\end{abstract}

Kata kunci: prestasi belajar ekonomi, afektif siswa, mind mapping

\section{Implementation of Mind Mapping to Improve Learning Achievement on the Topic of Economic Activities}

\begin{abstract}
The purpose of this research is to determine the application of the mind mapping learning model in improving the learning achievement of economic activity topic in class X IPS 1 students at SMA Negeri 1 Bambanglipuro in the 2020/2021 school year. In addition, it is also to determine the learning implementation process that applies the mind mapping model in improving learning achievement of economic activity topic. This research is a qualitative study using Classroom Action Research techniques. This Classroom Action Research Model uses the Kemmis McTaggart model and is implemented in 2 cycles. The main principle of this model is the provision of action in a gradual and continuous cycle in which there are four main stages of activity, namely planning, action, observation, and reflection. The data collection tools were used classroom observation, learning achievement tests, and documentation study. Observations are carried out directly in the action process. Data analysis used analytical descriptive analysis with the presentation of tables and percentages. Presentation of data in the form of percentages is then described and conclusions are drawn. The results of this study indicate that the application of this mind mapping learning model can improve student achievement. The increase in achievement can be seen in cycle I, there are 14 students (51.58\%) whose score is $\geq 70$ or the value is KKM and in cycle II there are 24 students (88.89\%) whose score is $\geq 70$ or the value is KKM, so the increase in learning completeness is $37,04 \%$ and the average increase in learning achievement from cycle I to cycle II was 14.81, from an average value of 62.04 in the first cycle to an average value of 76.85 in the second cycle. Student affective results also increased, namely in the first cycle only the category was sufficient and in the second cycle it became very good.
\end{abstract}

Keywords: achievement study in Economic, Students' Affective, mind mapping 


\section{Pendahuluan}

Ilmu pengetahuan dan teknologi di zaman globalisasi abad ke-21 ini, telah menyentuh segala komponen pendidikan maka arus informasi bisa dengan gampang diperoleh untuk menjadikan anak didik lebih aktif dan kreatif dalam partisipasi proses belajar. Proses pembelajaran mencakup beberapa unsur yang saling mempengaruhi dan berkaitan antar sesama unsur. Unsur tersebut adalah tujuan, materi bahan ajar, metode, model atau strategi pembelajaran, media, dan penilaian. Komponen dalam sistem pembelajaran ini yang sangat penting adalah tujuan pembelajaran dan model pembelajaran. Guru merupakan bagian penting dari pendidikan, peran fundamental dalam kegiatan belajar mengajar ini berguna membuat kondisi belajar yang efektif, ampuh dan efisien dalam mencapai tujuan pembelajaran. Guru harus bisa memakai model pembelajaran secara efektif dan inovatif dalam mengelola penyampaian konten atau materi pembelajaran untuk mencapai prestasi belajar.

Hasil belajar menurut Sudjana (2013: 3) "merupakan perubahan perilaku siswa yang disebabkan oleh pembelajaran". Menurut definisi Nawawi (1981: 117) prestasi belajar mengacu pada perilaku anak dalam kurikulum sekolah yang diwakili oleh skor perolehan dari evaluasi pada berbagai topik. Dari beberapa pendapat tersebut maka dapat diartikan prestasi belajar ialah sesuatu buah yang dapat diraih sesudah menempuh jalannya belajar yang dinampakkan dengan nilai atau raport pengetahuan, sikap, dan keterampilan dari hasil tes.

Proses belajar mengajar yang dialami oleh siswa metentukan keberhasilan prestasi belajar. Proses pembelajaran akan menjadikan siswa berubah dalam hal kognitif, pemahaman, penalaran, psykomotorik, nilai dan afektif. Untuk mengimplementasikan perubahan tersebut dengan benar, diperlukan banyak faktor guna menciptakan perubahan yang diinginkan, salah satunya ialah pemahaman konsep yang efektif melalui tepat pilihan model pembelajaran. Hal ini, Pendidik harus dituntut menguasai penggunaan bermacam-macam model pembelajaran agar siswa bisa melakukan aktifitas belajar lebih menyenangkan dan tidak membosankan. Hal ini dikarenakan siswa tidak hanya dijadikan objek, tetapi juga subjek.

Seleksi model pembelajaran yang pas dan efektif menjadi tindakan mendesak yang harus dilakukan guru saat melaksanakan pembelajaran, salah satunya model pembelajaran mind mapping. Secara perspektif yang sederhana istilah model mendekati serupa dengan strategi.
Maka model pembelajaran bisa dikatakan hampir serupa dengan strstegi pembelajaran. Menurut Fathurrohman (2017: 29) "Model pembelajaran adalah suatu model ideal yang dapat dipakai untuk acuan menjalankan belajar mengajar di kelas". Sedangkan menurut pemikirannya Trianto (2007: 1), model pembelajaran yakni rancangan terpola untuk digunakan sebagai landasan menjalankan aktivitas belajar di kelas atau tutorial pembelajaran. Model pembelajaran dapat di simpulkan bahwa merupakan kerangka yang konseptual dideskripsikan dan melukiskan tata cara yang teratur dalam menyelenggarakan pembelajaran dan sarana untuk mewujudkan tujuan belajar serta berguna untuk acuan dalam perencanaan bagi pendidik dalam menjalankan aktivitas belajar mengajar.

Mind mapping atau peta konsep menggambarkan suatu model pembelajaran yang ampuh untuk menjadikan paham suatu kerangka konsep materi ajar. Pemetaan pikiran dari pendapat Buzan (2006: 4) yakni trik termudah guna memasukkan bahan ajar ke dalam otak, membuat catatan yang kreatif dan efektif, serta menggambar cara berpikir untuk mendapatkan informasi dari otak. Menurut Martin (dalam Basuki, 2000: 22), menjelaskan bahwa Mind Mapping (peta pikiran) bagi guru, merupakan petunjuk untuk mengetahui hubungan antara gagasan-gagasan pokok dalam bahan ajar. Sedangkan menurut Arends (dalam Basuki, 2000: 25) menuliskan bahwa Mind Mapping (peta pikiran) bagi siswa menjadi suatu cara yang ampuh untuk mengingat dan pahami berbagai bahan ajar baru. Dengan pembuatan peta konsep yang bagus maka peserta didik dapat selalu ingat terhadap suatu bahan ajar yang diberikan guru serta menjadi lebih kreatf dan aktif. Berdasarkan pendapat-pendapat tersebut dapat dikatakan bahwa model pembelajaran mind mapping (peta pikiran) adalah suatu model belajar yang disusun untuk memotivasi siswa lebih kreatif dan aktif dalam menetapkan dan menata pokok-pokok materi yang penting dari bahan ajar. Model pembelajaran mind map dapat membantu siswa meningkatkan prestasi belajarnya dalam menguasai konsep mata pelajaran, serta dapat merangsang meningkatkan afektif siswa.

Hasil observasi peneliti di jurusan IPS Kelas $\mathrm{X}$ SMA Negeri 1 Bambangipuro menemukan beberapa masalah, diantaranya model pembelajaran yang digunakan tidak mampu meningkatkan prestasi belajar siswa, dan tingkat variasi model pembelajaran yang kecil sehingga siswa mudah bosan. Siswa cenderung pasif dan tidak berminat belajar, rata-rata prestasi belajar anak hanya 53,05 (masih lebih rendah dari KKM 
= 70), 16\% anak yang mencapai KKM, dan $84 \%$ anak yang tidak mencapai KKM.

Dilandasi permasalahan di atas perlu dilakukan penelitian agar siswa mampu meningkatkan prestasi belajar khususya pembelajaran ekonomi. Penelitian ini mencoba mengetahui secara empiris model pembelajaran dengan mind mapping bisa meningkatkan prestasi belajar siswa.

\section{Metode Penelitian}

Riset ini diklasifikasikan sebagai penelitian kualitatif dua siklus dengan menggunakan teknik Penelitian Tindakan Kelas. perencanaan, tindakan, observasi dan refleksi menjadi tahapan tiap siklusnya. Untuk pengambilan sampel dengan memakai purposive sampling yakni Siswa kelas X IPS 1 di SMAN 1 Bambanglipuro Bantul sejumlah 27 siswa yang terdiri dari perempuan sejumlah 20 siswa dan laki-laki sejumlah 7 siswa, sekaligus sebagai subjek penelitian. Penggunaan model pembelajaran yang telah dirancang tepat diterapkan pada siswa Kelas X IPS 1 SMAN 1 Bambanglipuro, sedangkan prestasi belajar siswa menjadi objek dalam penelitian ini.

Teknik pengambilan data pada riset ini memakai observasi, test prestasi belajar, dan dokumen. Observasi digunakan untuk memperoleh jenis data terkait perilaku siswa dan guru dalam proses pembelajaran ekonomi. Tes prestasi akademik menentukan jenis data dan tingkat ketuntasan belajar siswa yang berupa prestasi siswa. Dokumen berupa foto kegiatan pembelajaran, dan hasil pencatatan lapangan digunakan untuk mendukung data yang didapat selama kegiatan observasi.

Alat yang dipakai dalam riset ini merupakan instrumen prestasi belajar dan instrumen proses pembelajaran model mind mapping. Instrumen prestasi belajar berupa soal tes tertulis pilihan ganda sejumlah 20 butir soal dengan kisi-kisinya sudah dikaji dalam MGMP sekolah. Instrumen proses pembelajaran model mind mapping untuk mengukur afektif siswa dan proses pembelajaran. Instrumen observasi terdiri dari observasi untuk mengukur proses pembelajaran dengan 20 butir pertanyaan skala perbedaan semantic dan observasi untuk mengukur sikap afektif siswa dalam mengikuti proses pembelajaran dengan 6 butir pertanyaan skala perbedaan semantic juga (Fatimah, 2015: 10).

Kisi-kisi lembar observasi untuk mengukur afektif siswa mengadopsi dari Fatimah (2015: 13) yaitu kerajinan, perhatian, keaktifan. (4) kerapian, ketepatan, dan keberanian. Sedangkan kisi-kisi lembar observasi proses pembelajaran yaitu pelaksanaan, presentasi, karakteristik pribadi, kegiatan guru dan siswa selama belajar mengajar.

Dari hasil observasi, hasil tes prestasi akademik dan studi dokumen, data penelitian dianalisis dalam bentuk data kualitatif. Data penelitian yang berupa data kuantitatif dianalisis secara interpretatif melalui analisis deskriptif analitik (yaitu tabel dan persentase) yang bersifat eksplanatif. Kemudian mendeskripsikan representasi data berwujud persentase serta menarik kesimpulan tentang tiap-tiap komponen.

Hitungan persentase hasil observasi proses pembelajaran dan afektis siswa dirumuskan sebagai berikut :

$\%$ proses dan afeksif $=\frac{\text { skor total perolehan }}{\text { skor } \text { maksimal }} \times 100 \%$

Sedangkan persentase ketuntasan prestasi belajar peserta didik memakai pedoman berikut.

$$
K=\frac{T}{T t} x 100 \% \quad \begin{aligned}
& \mathrm{K}=\text { Ketuntasan Belajar } \\
& \mathrm{T}=\text { Skor siswa } \\
& \mathrm{Tt}=\text { Skor total }
\end{aligned}
$$$$
\text { (Trianto, } 2012: 63-64)
$$

Prosedur yang digunakan riset ini memakai model Kemmis McTaggart (dalam Dwitagama, 2010: 21) "yang terdapat beberapa tahapan yaitu tahap rencana, tahap tindakan, tahap pengamatan dan tahap refleksi”

Tahap perencanaan, peneliti merencanakan skenario dan menyiapkan media, alat serta fasilitas lainnya guna melaksanakan tindakan kemudian melakukan simulasi tindakan untuk mereduksi kesalahan. Tahap tindakan yakni mengimplementasikan skenario pembelajaran di kelas dengan menngunakan model pembelajaran mind mapping. Tahap pengamatan dilakukan selama proses pembelajaran dengan bantuan dua kolaborator. Tahap refleksi ini menganalisis hasil observasi, dokumen catatan lapangan, rekaman data, hasil diskusi dan temuan lainnya. Hasil analisis digunakan untuk dasar perbaikan di siklus selanjutnya dalam pembelajaran".

Selanjutnya sintak model pembelajaran mind mapping dalam riset ini mengadopsi dari pendapatnya Lestari dan Yudhanegara (2015: 76) yang intinya yakni 1) Guru membuka dengan doa, presensi, dan menginformasikan $\mathrm{KD}$ yang akan dicapai serta memberi apersepsi, 2) Guru menyampaikan materi secara singkat dengan batuan mind mapping, 3) Guru membentuk kelompok terdiri dari 3-4 siswa dan menjelaskan cara membuat mind mapping, 4) Tiap kelompok melakukan diskusi tentang materi dan membuat mind mappingnya dengan panduan lembar kerja kelompok, 5) Diskusi kelompok selesai, guru menunjuk beberapa perwakilan kelompok untuk mempresentasikan hasil berupa mind mapping 
materi dan kelompok lain menanggapi, 6) Setelah selesai presentasi guru memberikan umpan balik dan menyimpulkan materi bersama siswa.

Penelitian tindakan kelas yakni riset terhadap tindakan yang dilaksanakan di kelas guna memperbaiki dan meningkatkan kwalitas pembelajaran. Riset tindakan ini menggunakan 2 (dua) siklus, dimana tiap siklus terdapat 2 (dua) kali tatap muka. Kedua siklus ini membahas topik kegiatan ekonomi yang terdiri dari 4 sub topik. Siklus I tatap muka ke 1 membahas konsep kegiatan ekonomi, siklus I tatap muka ke 2 membahas perilaku kegiatan ekonomi, siklus II tatap muka ke 1 membahas pelaku kegiatan ekonomi dan perannya, siklus II tatap muka ke 2 membahas tentang diagram interaksi antar pelaku dalam kegiatan ekonomi.

Tiap siklus dilakukan 4 (empat) tahapan seperti diuraikan di atas. Jika siklus pertama hasilnya belum ada peningkatan maka dilanjutkan pada siklus selanjutnya sampai penelitian merasa berhasil dengan adanya peningkatan sesuai harapan.

Kegiatan pada siklus 1 melakukan proses pembelajaran yang dirancang dalam dua kali tatap muka. Proses pembelajaran dirancang dan didukung dengan menyiapkan media, LKK, daftar kelompok siswa, supaya berjalan lancar dan materi mudah dipelajari. Peneliti dalam melakukan proses pembelajaran dibantu oleh kolaborator untuk melakukan observasi.

Hasil observasi kelas dibawa ke forum refleksi untuk dianalisis oleh penelitian bersama kolaborator secara bersama-sama. Hasil analisis tersebut kemudian digunakan untuk merencanakan kagiatan pada siklus berikutnya. Tindakan yang sukses diteruskan pada proses belajar berikutnya, sedangkan tindakan yang tidak sukses dimodifikasi dan diperbaiki

Hasil yang tercermin dari tindakan pada Siklus 1 digunakan sebagai dasar untuk merevisi Siklus 2. Tindakan pada siklus 2 merupakan kelanjutan dari siklus 1 yang tidak memenuhi standar yang berlaku. Peneliti memperbaiki rancangan siklus 2 didasarkan dari temuantemuan dan refleksi siklus 1 . Tindakan siklus 2 ini diharapkan hasilnya sudah sesuai dengan indikator keberhasilan penelitian sehingga berhenti sampai pada siklus ini.

Komponen yang jadi penanda keberhasilan pada prestasi belajar siswa yakni apabila setidaknya $75 \%$ siswa dalam satu kelas meraih ketuntasan belajar dari satu siklus ke siklus selanjutnya dengan penuhi Kriteria Ketuntasan Minimun (KKM) yang sudah ditetapkan sekolah adalah $\geq 70$.

\section{Hasil dan Pembahasan}

Penelitian tindakan kelas dilaksanakan dalam dua siklus. Setiap siklus mencakup 2 kali tatap muka. Tes tertulis akan diberikan di akhir setiap siklus. Fokus riset ini adalah peningkatan prestasi belajar siswa pada topik kegiatan ekonomi dengan menerapkan model pembelajaran mind mapping.

Siklus 1 pembelajaran diawali dengan perencanaan supaya proses pembelajaran berjalan lancer dan efektif. Perencanaan yang dilakukan yaitu menyusun silabus, RPP, membuat lembar kerja kelompok (LKK), membentuk daftar kelompok secara acak, menyiapkan media, menyusun soal tes, menyusun lembar observasi. Tahap pelaksanaan tindakan di dalam kelas diawali dengan berdoa, mengasben kehadiran siswa dan memastikan kondisi kelas dalam keadaan bersih. Kemudian, guru melangsungkan apersepsi dengan dilontarkannya pertanyaan yang berhubungan dengan sub pokok bahasan yang hendak diajarkan. Guru menanyakan contoh kegiatan ekonomi sebelum berangkat ke sekolah tadi. Guru juga menyampaikan kompetensi yang hendak dicapai dan urutan langkah pembelajaran.

Aktifitas inti pembelajaran, guru menerangkan poin-poin pokok bahan ajar macam kegiatan ekonomi dengan bantuan LCD, dilanjutkan siswa berdiskusi kelompok membuat mind mapping dengan panduan lembar kerja kelompok. Saat diskusi kelompok membuat mind mapping terjadi interaksi antar siswa dan sudah mulai aktif namun banyak siswa masih merasa kebingungan dalam pembuatan mind mapping. Upaya mengatasinya guru berkelililing mendampingi kelompok dalam membuat mind mapping. Diskusi kelompok selesai dilanjutkan mempresentasikan hasil diskusi. Kelompok yang melakukan penyajian hasil, yakni dengan menjelaskan materi dengan bantuan mind mapping yang dibuat. Kelompok yang belum mendapat giliran presentasi, menyimak dan menyiapkan secara aktif daftar permasalahan berupa pertanyaan atau memberikan saran, bahkan ikut membantu menjawab pertanyaan yang belum terjawab oleh kelompok penyaji. Seperti itulah proses presentasi dijalankan sampai batas waktu berakhir. Tatap muka 1 siklus 1 ini ada 3 kelompok berhasil melakukan presentasi. Tatap muka 2 siklus 1 kegiatan pembelajaran hampir sama dengan tatap muka 1 namun siswa sudah mulai banyak yang aktif dan sedikit siswa yang bingung dalam pelaksanaan diskusi. Kelompok yang berhasil melakukan presentasi juga bertambah yang sebelumnya 2 
kelompok menjadi 6 kelompok. Guru memberikan umpan balik simpulan materi yang dilakukan siswa pada akhir pembelajaran. Guru juga menyampaikan simpulan singkat tentang materi yang diberikan.

Tahap pengamatan dilakukan dengan memberikan tes tertulis dan obervasi jalannya proses pembelajaran serta afektif siswa. Hasil observasi proses pembelajaran pada siklus I ini didapatkan skor observasi proses pembelajaran penerapan model mind mapping sebesar 64 atau 64\% masuk katergori cukup di tatap muka ke 1 dan sebesar 67 atau $67 \%$ masuk katergori cukup di tatap muka ke 2. Jadi pada siklus 1 ini dari tatap muka ke 1 dan tatap muka 2 belum ada kenaikan yang signifikan. Hasil observasi afektif siswa dalam diskusi kelompok model pembelajaran mind mapping siklus I diperoleh rerata ketercapaian afektif siswa baru 56,4\% pada tatap muka ke 1 menjadi $64,2 \%$ pada tatap muka ke 2 dan masih kategori cukup.

Tabel 1 berikut menunjukkan hasil prestasi belajar yang diperoleh dengan menerapkan model pembelajaran mind map pada Siklus I.

Tabel 1 Ketercapaian KKM Siklus I

\begin{tabular}{lcc}
\hline \multicolumn{1}{c}{ Standar Nilai } & Frek & $\%$ \\
\hline $\mathrm{N} \geq 70$ (sudah KKM) & 14 & $51,85 \%$ \\
$\mathrm{~N}<70$ (belum KKM) & 13 & $48,15 \%$ \\
Total kehadiran & 27 & $100 \%$ \\
Total Absen & 0 & $0 \%$ \\
Nilai rerata & \multicolumn{2}{c}{62,04} \\
\hline
\end{tabular}

Berdasarkan tabel 1 di atas, nilai rata-rata 62,04 pada siklus 1. Dilihat dari aspek ketuntasan belajar ada 14 siswa $(51,85 \%)$ nilainya mencapai $\geq 70$ (tuntas) atau sudah KKM dan ada 13 siswa $(48,15 \%)$ nilainya $<70$ (belum tuntas) atau belum KKM. Capaian ketuntasan tersebut belum sesuai dengan indikator keberhasilan yang ditetapkan.

Tahap refleksi melakukan pencermatan lagi skor prestasi belajar, skor observasi proses pembelajaran dalam penerapan mind mapping dan skor afektif siswa. Tujuan dari refleksi ini untuk mengetahui kendala atau kekurangan di siklus 1. Hasil refleksi siklus I diperoleh permasalahan atau kendala yaitu; siswa belum kelihatan aktif, guru kesulitan dalam pengelolaan kelas, siswa masih kebingungan dalam membuat mind mapping, lembar kerja kelompok (LKK) belum ada contoh hasil mind mapping, serta manajemen waktu baik. Bersama kolaborator melakukan pemecahan masalah atau kendala tersebut dan langkah perbaikan untuk dilaksanakan pada siklus II. Pemecahan masalah atau kendala yang dilakukan yaitu (1) memperbanyak tanya jawab dalam penyampaian materi dan memotifasi siswa supaya menaikan keaktifan dalam diskusi kelompok, (2) merubah cara penyajian bahan ajar dengan memakai media PPT yang menarik dan alat LCD sehingga siswa akan tertarik dan fokus, (3) Peneliti dibantu kolaborator berkeliling ke masingmasing kelompok saat membuat mind mapping untuk membantu kesulitan yang dialami siswa, (4) lembar kerja kelompok (LKK) deberi beberapa contoh mind mapping dan latihan soal yang modelnya membantu siswa dalam membuat mind mapping sehingga memotivasi ide dan kreatifitas, (5) memperbaiki manajemen waktu terutama pembagian kegiatan inti, alokasi untuk diskusi kelompok dan presentasi.

Tahap perencanaan, tahap tindakan, tahap observasi dan tahap refleksi pada jalannya siklus II sama dengan jalannya siklus I namun jalannya siklus II ada beberapa perbaikan supaya kendala atau masalah yang timbul di siklus I tidak terulang lagi. Hasil observasi proses pembelajaran pada siklus II ini didapatkan skor observasi proses pembelajaran penerapan model mind mapping sebesar 77 atau $77 \%$ masuk katergori baik di tatap muka ke 1 dan sebesar 89 atau $89 \%$ masuk katergori sangat baik di tatap muka ke 2. Pada siklus II ini proses penerapan model pembelajaran mind mapping ada peningkatan yang siknifikan karena kategori pada siklus 1 hanya cukup sedangkan di siklus II meningkat masuk kriteria baik, dan sangat baik.

Hasil observasi afektif siswa dalam diskusi kelompok model pembelajaran mind mapping siklus II diperoleh rerata ketercapaian afektif siswa $74,1 \%$ pada tatap muka ke 1 menjadi $86,2 \%$ pada tatap muka ke 2, hasil ini tergolong baik dan sangat baik. Pada siklus II ini afektif siswa dalam diskusi kelompok mind mapping ada peningkatan yang siknifikan karena kategori pada siklus I hanya cukup dan di siklus II sangat baik.

Tabel 2 berikut menunjukkan hasil prestasi belajar yang diperoleh dengan menerapkan model pembelajaran mind map pada Siklus II.

Tabel 2 Ketercapaian KKM Siklus II

\begin{tabular}{lcc}
\hline \multicolumn{1}{c}{ Standar Nilai } & Fre & $\%$ \\
\hline $\mathrm{N} \geq 70$ (sudah KKM) & 24 & $88,89 \%$ \\
$\mathrm{~N}<70$ (belum KKM) & 3 & $11,11 \%$ \\
Total kehadiran & 27 & $100 \%$ \\
Total absen & 0 & $0 \%$ \\
Nilai rerata & \multicolumn{2}{c}{76,85} \\
\hline
\end{tabular}

Berdasarkan tabel 2, nilai rata-rata 76,85 pada siklus II. Dilihat dari aspek ketuntasan belajar ada 24 siswa $(88,89 \%)$ nilainya mencapai $\geq 70$ (tuntas) atau sudah KKM dan ada 3 siswa $(11,11 \%)$ nilainya $<70$ (belum tuntas) atau 
belum KKM. Capaian ketuntasan prestasi belajar pada siklus II tersebut sudah sesuai dengan indicator keberhasilan penelitian yang ditentukan yaitu terdapat $\geq 70 \%$ siswa tuntas atau mencapai KKM. Keberhasilan capaian pada siklus II tentunya tidak terlepas dari hasil perbaikan dalam proses pembelajaran sebagai hasil refleksi dari siklus I. Hasil ini diperkuat risetnya Warniningsih (2019: 47) yang menyimpulkan bahwa "Model mind mapping dapat meningkatkan prestasi belajar ekonomi pada siswa kelas X IPA SMA Negeri 1 Galur Kulon Progo, peningkatan prestasi belajar terlihat yang sebelumnya ketuntasannya hanya $72,53 \%$ menjadi 82,63\%" dan menurut Hidayat (2016: 129) yang dilaksanakan sebelumnya, "hasil belajar peserta didik sesudah proses belajar mengajar dengan mengimplementasikan model mind mapping pada pelajaran IPS mengalami peningkatan yang semula ketuntasannya hanya $60 \%$ menjadi $88,5 \% "$

\section{Simpulan dan Saran}

Mengacu pada hasil dan ulasan penelitian yang sudah diurakan di atas, maka dapat disimpulkan sebagai berikut; proses pelaksanaan pembelajaran yang menerapkan model mind mapping yang awalnya kategori cukup di siklus I menjadi sangat baik di siklus II. Terlihat perolehan skor observasi proses belajar mendapat 67\% (kategori cukup) di siklus I menjadi 89\% (kategori sangat baik) di siklus II. Jadi dapat dikatakan terjadi perubahan tingkat kualitas pada proses pembelajaran.

Penerapan model pembelajaran mind mapping mampu meningkatkan afektif siswa dalam diskusi kelompok. Terlihat perolehan skor observasi afektif siswa sebesar $64,2 \%$ (kategori cukup) di siklus I menjadi 86,2\% (kategori sangat baik) di siklus II.

Implementasi model mind mapping bisa meningkatkan prestasi belajar siswa pada topik kegiatan ekonomi. Peningkatan prestasi terlihat di siklus I ada 14 siswa $(51,58 \%)$ yang nilainya $\geq$ 70 atau nilainya sudah KKM dan di siklus II ada 24 siswa $(88,89 \%)$ yang nilainya $\geq 70$ atau nilainya sudah KKM. Jadi peningkatan ketuntasan belajar sebesar 37,04\%.

Berlandaskan hasil penelian yang sudah disampaikan di atas, ada beberapa saran diberikan; pendidik atau guru sebaiknya mengimplementasikan model pembelajaran yang variatif supaya tidak terjadi kejenuhan pada siswa. Model ini jadi satu alternatif sebagai solusi yaitu dengan diimplementasikannya model mind mapping. Model ini bisa dipakai oleh guru mata pelajaran rumpun IPA, rumpun IPS maupun rumpun Bahasa.

Siswa disarankan tetap menjaga capaian prestasi pengetahuan dan sikap yang sangat baik ini pada materi-materi selanjutnya atau pada mata pelajaran lainnya bila menngunakan model mind mapping. Model mind mapping bisa menjadi alternatif yang dapat digunakan meningkatkan prestasi belajar siswa terutama pada materimateri yang banyak hafalannya. Penelitian selanjutnya disarankan dalam pembuatan lembar kerja kelompok benar-benar harus detail dan merangsang memunculkan ide membuat mind mapping. Alokasi harus diperhitungkan secara detai supaya tidak merasa kekurangan waktu dalam proses pembelajaran.

\section{Daftar Pustaka}

Basuki, T. (2000). Pembelajaran Matematika Disertai Penyusunan Peta Konsep. Bandung: PPS UPI Bandung.

Buzan, T. (2006). Buku Pintar Mind Map. Jakarta: PT Gramedia Pustaka Utama.

Dwitagama, W. K. (2010). Mengenal Penelitian Tindakan Kelas. Jakarta: PT Indeks.

Fathurrohman, M. (2017). Model-Model Pembelajaran Inovatif. Jakarta: Ar-Ruzz Media.

Fatimah, I. (2015). Upaya Peningkatan Prestasi Belajar Kimia Siswa Kelas XII IPA SMA Negeri 1 Bambanglipuro Bantul Menggunakan Mind Mapping. Bantul: Perpustakaan Widya Lipura.

Hidayat, S. (2016). Penerapan Model Pembelajaran Mind Mapping Untuk Meningkatkan Hasil Belajar Mata Pelajaran IPS di Sekolah Dasar. JPGSD, 129.

Lestari, K.E dan Yudhanegara, M.R. (2015). Penelitian Pendidikan Matematika. Bandung: PT Refika Aditama.

Nawawi. (1981). Psikologi Pendidikan. Jakarta: Balai Pustaka.

Sudjana, N. (2013). Dasar-Dasar Proses Belajar Mengajar. Bandung: Sinar Baru.

Trianto. (2007). Model Pembelajaran Terpadu dalam Teori dan Praktik. Jakarta: Prestasi Pustaka Publisher.

Trianto. (2012). Panduan Lengkap Penelitian Tindakan Kelas Teori dan Praktik. Jakarta: Prestasi Pustaka Publisher.

Warniningsih, E. (2019). Peningkatan Prestasi Belajar Ekonomi Siswa Kelas X IPA 1 Lintas Minat SMA Negeri 1 Galur Menggunakan Mind Mapping. Ideguru: Jurnal Karya Ilmiah Guru, 4(1), 46-57. https://doi.org/10.51169/ideguru.v4i1.68 